\title{
Diversity and distribution of amoA-type nitrifying and nirS-type denitrifying microbial communities in the Yangtze River estuary
}

\author{
Y. Zhang ${ }^{1,2, *}$, X. Xie ${ }^{1,2, *}$, N. Jiao ${ }^{1,2}$, S. S.-Y. Hsiao ${ }^{3}$, and S.-J. Kao ${ }^{1,3}$ \\ ${ }^{1}$ State Key Laboratory of Marine Environmental Sciences, Xiamen University, Xiamen, China \\ ${ }^{2}$ Institute of Marine Microbes and Ecospheres, Xiamen University, Xiamen, China \\ ${ }^{3}$ Earth System Science Program, Taiwan International Graduate Program, Research Center for Environmental Changes, \\ Academia Sinica, Taipei, Taiwan \\ *These authors contributed equally to this work.
}

Correspondence to: Y. Zhang (yaozhang@xmu.edu.cn) and N. Jiao (jiao@xmu.edu.cn)

Received: 23 October 2013 - Published in Biogeosciences Discuss.: 15 November 2013

Revised: 11 February 2014 - Accepted: 3 March 2014 - Published: 16 April 2014

\begin{abstract}
Coupled nitrification-denitrification plays a critical role in the removal of excess nitrogen, which is chiefly caused by humans, to mitigate estuary and coastal eutrophication. Despite its obvious importance, limited information about the relationships between nitrifying and denitrifying microbial communities in estuaries, and their controlling factors have been documented. We investigated the nitrifying and denitrifying microbial communities in the estuary of turbid subtropical Yangtze River (YRE), the largest river in Asia, by analyzing the ammonia monooxygenase gene $a m o A$, including archaeal and bacterial amoA, and the dissimilatory nitrite reductase gene nirS using clone libraries and quantitative PCR (qPCR). The diversity indices and rarefaction analysis revealed a quite low diversity for both $\beta$ proteobacterial and archaeal amoA genes, but qPCR data showed significantly higher $a m o A$ gene copy numbers for archaea than $\beta$-proteobacteria. Compared with the amoA gene, a significantly higher level of diversity but lower gene copy numbers were found for the nirS gene. Nitrification and denitrification rates based on ${ }^{15} \mathrm{~N}$ incubation experiments supported gene abundance data as denitrification rates were below detection limit, suggesting lower denitrification than nitrification potential. In general, the abundances of the amoA and nirS genes were significantly higher in the bottom samples than the surface ones, and in the high-turbidity river mouth, were significantly higher in the particle-associated $(>3 \mu \mathrm{m})$ than the free-living $(0.2 \sim 3 \mu \mathrm{m})$ communities. Notably, positive correlations between the amoA and nirS gene abundances suggested potential gene-based coupling
\end{abstract}

between nitrification and denitrification, especially for the particle-associated assemblages. Statistical analysis of correlations between the community structure, gene abundances and environmental variables further revealed that dissolved oxygen and total suspended material might be the key factors controlling community spatial structure and regulating nitrification and denitrification potentials in the YRE ecosystem.

\section{Introduction}

The estuary channels the continuously increasing load of anthropogenic nitrogen $(\mathrm{N})$ from land to the coastal and shelf marine ecosystem. During the transportation, tightly coupled nitrification-denitrification and nitrification-anammox processes mediated by microorganisms may diminish the $\mathrm{N}$ loading to relieve the eutrophication stress. Nitrifiers supply oxidized $\mathrm{N}$ for denitrification or anammox, then denitrifiers release $\mathrm{N}$ via the conversion of oxidized $\mathrm{N}$ into gaseous $\mathrm{N}$ forms, such as nitrogen monoxide (NO), nitrous oxide $\left(\mathrm{N}_{2} \mathrm{O}\right)$ and nitrogen gas $\left(\mathrm{N}_{2}\right)$, and anammox bacteria release $\mathrm{N}$ by oxidizing ammonium with oxidized $\mathrm{N}$ to $\mathrm{N}_{2}$. Coupled nitrification-denitrification is reported to possibly regulate nitrate accumulations in estuary ecosystems (Taylor and Townsend, 2010) and remove up to $50 \%$ of external dissolved inorganic nitrogen (DIN) that enters into estuaries (Seitzinger et al., 2006), especially in the hypoxia zone. However, few studies have been devoted to understanding the 
relationship between nitrification and denitrification in estuaries by comparison between nitrifying and denitrifying microbial communities.

The Yangtze River, Changjiang, is the largest river in Asia in terms of volume of water discharge and length, and the third longest in the world. The Yangtze River estuary (YRE) lies at the interface between the Asian continent and East China Sea, and its water and suspended solid discharge is $9 \times 10^{11} \mathrm{~m}^{3}$ year $^{-1}$ and $4.9 \times 10^{8}$ tyear $^{-1}$, respectively (Lin and $\mathrm{Wu}, 1999)$. The DIN discharge from the Yangtze River to the estuary has increased by $6 \times$ in the past 5 decades (Wang, 2006; Yan et al., 2010). The intensive application of fertilizer and erosion of agriculture soil contribute to the high turbidity and heavily imbalanced $\mathrm{N} / \mathrm{P}$ ratio (often $>80$ even up to $200)$ of the YRE. Moreover, summer hypoxia $\left(<2 \mathrm{~m} \mathrm{~L}^{-1}\right.$ of dissolved oxygen (DO) concentration) was often observed in the bottom water of YRE (Wei et al., 2007; Wang, 2009; Zhu et al., 2011; Wang et al., 2012), and its areal extent has kept expanding since 1960 (Zhu et al., 2011). Whether or not denitrifying bacteria and their activity can be determined in the YRE ecosystem is critical in terms of mitigating the imbalanced nutrient status; meanwhile, the relation between nitrifying and denitrifying communities in such a turbid and N-replete estuary remains unexplored.

The ammonia-oxidizing archaeal (AOA) and bacterial (AOB) amoA gene putatively encodes $\alpha$ subunit of the ammonia monooxygenase enzyme, which is responsible for catalyzing the oxidation of ammonia to hydroxylamine, the first and rate-limiting step of nitrification. Quantitative analysis of the amoA gene shows that $\mathrm{AOA}$ are ubiquitous and greatly outnumber AOB in many environments (Leininger et al., 2006; Wuchter et al., 2006; De Corte et al., 2009; Abell et al., 2010). However, mounting evidence also suggests that AOB amoA gene abundance may actually be greater than AOA in certain regions of estuaries (Santoro et al., 2008; Wankel et al., 2011). The key enzyme in the dissimilatory denitrification pathway is nitrite reductase, which catalyzes the reduction of nitrite $\left(\mathrm{NO}_{2}^{-}\right)$to $\mathrm{NO}$, the first step in denitrification to produce gaseous $\mathrm{N}$. The nirS and nirK genes encode cytochrome cd1 and copper-containing nitrite reductase, respectively. They are functionally and physiologically equivalent, but structurally different and cannot be detected in the same strains (Coyne et al., 1989). The nirS gene is more widely distributed than the nirK gene (Zumft, 1997; Bothe et al., 2000). It is reported that nitrite reductase genes are dominated by the nirS but not the nirK types in a turbid subtropical estuary of central Queensland (Abell et al., 2010). Another study on the sediments of the River Clone estuary (United Kingdom) shows that only the nirS gene is significantly expressed in microbial communities (Nogales et al., 2002).

In this study, $\mathrm{AOA}$ and $\mathrm{AOB}$ amoA and bacterial nirS genes were investigated to analyze the diversity, abundance and spatial dynamics of nitrifiers and denitrifiers and their control environmental factors in the YRE during a spring and summer cruise (April and August 2011). The goals of this research were to (1) explore the spatial and temporal variation of the amoA and nirS genes, (2) evaluate the potential coupling between the nitrifier and denitrifier communities, and (3) identify the possible key environmental factors regulating the distribution of the amoA-type nitrifiers and nirS-type denitrifiers in the YRE.

\section{Materials and methods}

\subsection{Study sites and sampling}

A $177 \mathrm{~km}$ transect with five study sites (Y1 to Y5) along the salinity gradient from the YR mouth to the open water were sampled during a spring and summer cruise (7 to 18 April and 15 to 24 August 2011). A $222 \mathrm{~km}$ transect with six sites (YE0 to YE5) along the latitude gradient at $122.8^{\circ} \mathrm{E}$ longitude and a closest-to-seashore site Y0 were sampled only during the summer cruise (Fig. 1). In total, fifty samples were collected from the surface (1-5 m) and bottom (7$50 \mathrm{~m}$ ) of each station (Table S2), except for site YE0, where only the surface water was sampled. Water samples were collected with a SeaBird SBE 9/11 Plus CTD system. One or two liter samples for gene analysis were filtered first through $3 \mu \mathrm{m}$-pore-size and then $0.2 \mu \mathrm{m}$-pore-size polycarbonate filters ( $47 \mathrm{~mm}$ diameter, Millipore) at a pressure of $<0.03 \mathrm{MPa}$. The $3 \mu \mathrm{m}$-pore-size polycarbonate filters were designated as particle-associated communities and the $0.2 \mu \mathrm{m}$-pore-size ones were taken as free-living communities. Only the August samples were divided into size fractions of $>3 \mu \mathrm{m}$ and $0.22-3 \mu \mathrm{m}$, while only the $0.22-3 \mu \mathrm{m}$ free-living communities were sampled during the April cruise. Filtered samples were immediately frozen on board at $-20^{\circ} \mathrm{C}$ and transferred to $-80^{\circ} \mathrm{C}$ in the laboratory until further analysis.

\subsection{Biogeochemical analysis}

Temperature and salinity were measured using a CTD system. DO concentrations were measured using the Winkler method. Inorganic nutrients (ammonium, nitrate + nitrite, phosphate, silicate) were measured onboard using a flow injection analyzer (AA3 system and Tri-223 autoanalyzer) and standard spectrophotometric methods (Dai et al., 2011). Total suspended material (TSM) was collected by filtering 1-4 L water sample onto pre-combusted GF/F membrane (Whatman) and weighed.

\subsection{DNA extraction, PCR, cloning and sequencing}

DNA was extracted using the UltraClean Soil DNA kit (MoBio, San Diego, CA, USA) following the manufacturer's instructions. Archaeal and $\beta$-proteobacterial amoA gene sequences were amplified using primer sets ArchamoAF and Arch-amoAR (Francis et al., 2005) and amoA$34 \mathrm{~F}$ and amoA-2R (Kim et al., 2008), respectively; the 


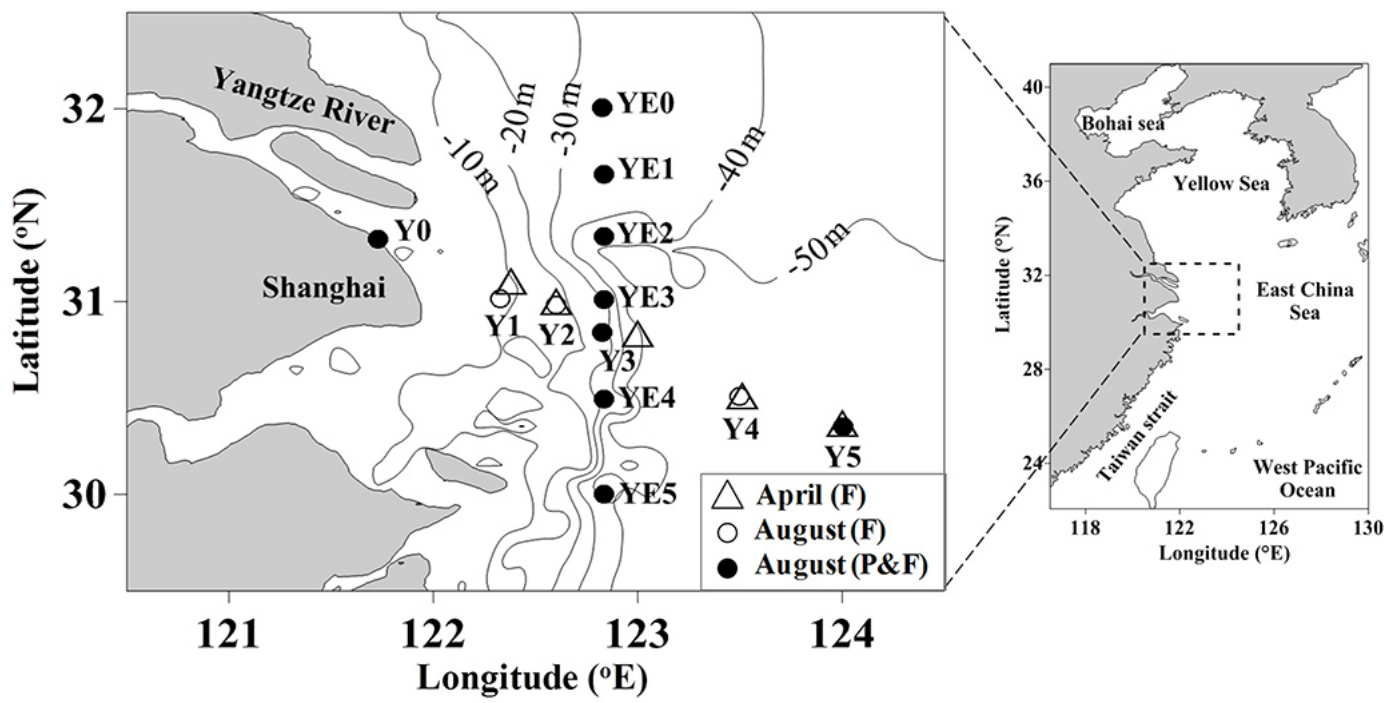

Fig. 1. Location of the study sites in the Yangtze River estuary of the East China Sea. Isobaths are used as the background. F: free-living samples; P: particle-associated samples.

$\gamma$-proteobacterial amoA gene was not amplified successfully from these samples using primers amoA-3F and amoB-4R (Purkhold et al., 2000). The nirS gene fragments were amplified using primers nirS-1F and nirS-6R (Braker et al., 1998). The PCR reaction mixture for amplifying the $a m o A$ gene was prepared in accordance with Hu et al. (2010) and PCR conditions were applied as described by Francis et al. (2005) and Kim et al. (2008). The PCR reaction mixture $(25 \mu \mathrm{L})$ for amplifying the nirS gene contained $12.5 \mu \mathrm{L}$ of Premix Ex Taq (TakaRa, Dalian, China), $1.6 \mu \mathrm{M}$ of each primer, $50 \mu \mathrm{g}$ BSA and $1.5 \mu \mathrm{L}$ template, and PCR conditions were applied as described by Oakley et al. (2007). Amplification products were purified using an agarose gel DNA purification kit (TaKaRa), ligated into the pMD18-T vector (TakaRa) and then transformed into competent cells of Escherichia coli DH5 $\alpha$. Positive clones were screened using PCR re-amplification with vector primers M13-F/M-13R and randomly selected for sequencing using an ABI model 3730 automated DNA sequence analyzer with BigDye terminator chemistry (Applied Bio Systems, Perkin-Elmer).

\subsection{Phylogenetic diversity analysis}

AmoA and nirS gene sequences were grouped into operational taxonomic units (OTUs) based on a $5 \%$ sequence divergence cutoff (Oakley et al., 2007; Wankel et al., 2011) using the DOTUR program (Schloss and Handelsman, 2005). Rarefaction, non-parametric coverage and phylotype richness estimators (Chao 1, Shannon and Simpson) for each clone library were also calculated using DOTUR.

DNA sequences were analyzed using the BLASTN tool, and amino acid sequences were analyzed using BLASTP to aid the selection of the closest reference sequences.
Neighbor-joining phylogenetic trees were constructed in MEGA5 using the Maximum Composite Likelihood model with DNA sequences for the amoA gene and the Poisson model with translated amino acid sequences for the nirS gene. DNA sequences with $>95 \%$ similar identity were grouped into the same phylotype.

\subsection{Quantitative PCR amplification}

Abundances of the nirS gene and $\beta$-proteobacterial and archaeal amoA gene were quantified using the quantitative PCR (qPCR) method and a CFX $96^{\mathrm{TM}}$ real-time system (BIO-RAD, Singapore). The $\beta$-proteobacterial amoA gene was amplified using primers amoA-1F and amoA-2R (Kim et al., 2008); the archaeal amoA gene was amplified using primers Arch-amoAF and Arch-amoAR (Francis et al., 2005); and the nirS gene was amplified using primers nirS-1F and nirS-3R (Braker et al., 1998; Huang et al., 2011). Standard curves were constructed for the $\beta$ proteobacterial amoA gene using the plasmid DNA of the most dominant genotype clone Aug Y3SF15 (KF362529); for the archaeal amoA gene using a mixture of equal amounts of the plasmid DNA of the four most dominant genotype clones AugY0SP01 (KF362930), AugY0SP03 (KF362932), AprY3BF01 (KF362819) and AugY5BP02 (KF363129); and for the nirS gene using a mixture of equal amounts of the plasmid DNA of the two most dominant genotype clones AprY5BF_63 (KF363544) and AprY4BF_01 (KF363527). Using ten-fold increments, the standard concentrations were adjusted from $10^{7}$ to $10^{0}$ gene copies $\mu \mathrm{L}^{-1}$ for the $\beta$-proteobacterial amoA and nirS genes, and from $10^{8}$ to $10^{1}$ gene copies $\mu \mathrm{L}^{-1}$ for the archaeal amoA gene. QPCR amplification for the amoA gene was carried out as described 
previously (Mincer et al., 2007; Hu et al., 2011). For the amplification of the nirS gene, the reaction mixture $(25 \mu \mathrm{L})$ contained $12.5 \mu \mathrm{L}$ SYBR $^{\circledR}$ Premix Ex Taq ${ }^{\mathrm{TM}}$ II (TakaRa, Dalian, China), $0.5 \mu \mathrm{M}$ of each primer and $1 \mu \mathrm{L}$ template DNA, and qPCR thermal cycling conditions were applied as described by Huang et al. (2011). The amplification efficiencies of PCR were always between 85 and $95 \%$ with $R^{2}$ values $>0.99$. The specificity of the qPCR reactions was confirmed by melting curve analysis, agarose gel electrophoresis and sequencing analysis.

\subsection{Statistical analysis}

Non-metric multidimensional scaling (NMDS) was used to determine the community structure similarity between samples with PRIMER (Clarke and Gorley, 2001). Bray-Curtis similarities were calculated on the OTU relative abundance matrices. The similarities were presented in a multidimensional space by plotting more similar samples closer together (Kruskal, 1964a, b). One-way analysis of similarity (ANOSIM) with 999 permutations was used to test for the significance of the differences in community composition among various NMDS clusters (Clarke, 1993). Correlations between the community structure and environmental factors were analyzed using CANOCO software (version 4.5, Microcomputer Power, USA) (Ter-Braak, 1989). The redundancy analysis (RDA) was chosen when the maximum gradient length of detrended correspondence analysis was shorter than 3.0, otherwise canonical correspondence analysis (CCA) was chosen (Lepš and Šmilauer, 2003). The environmental variables were normalized via $\mathrm{Z}$ transformation (Magalhães et al., 2008). Optimal CCA models were produced with automatic forward selection via Monte Carlo permutation significance tests (999 permutations). A paired or unpaired $t$ test for comparison of two variables was performed using the SPSS (18.0) software package (SPSS Inc., Chicago, IL, USA).

\section{$2.7 \quad{ }^{15} \mathrm{~N}$ Incubation experiments}

Nitrification and denitrification rates were measured using stable isotopic tracer methods based on Lipschultz et al. (1986). Details of the experiment procedures and calculation are described in Hsiao et al. (2014) and Hsu and Kao (2013).

\section{Nucleotide sequence accession number}

The GenBank submission numbers for the sequences from this study are KF362134-363544.

\section{Results}

\subsection{Biogeochemical characteristics of the region studied}

Salinity ranged from 22.2 to 34.1 in April and 0.2 to 34.4 in August over our sampling sites. DO concentrations ranged from 8.3 to 11.7 and 2.6 to $8.0 \mathrm{mg} \mathrm{L}^{-1}$ in the two cruises, respectively, and were significantly lower in the bottom than the surface waters $(P=0.000$, paired $t$ test $)$ and in August rather than April ( $P=0.000$, unpaired $t$ test). The DO minimum occurred at the bottom of site YE2 in August, but did not reach the threshold of hypoxia $\left(2 \mathrm{mg} \mathrm{L}^{-1}\right)$ (Renaud, 1986). TSM was measured only in August, and showed a strong gradient decreasing seaward, ranging from 2.5 to $261.8 \mathrm{mg} \mathrm{L}^{-1}$. TSM concentrations were significantly higher in the bottom samples than those in the surface ones $(P=$ 0.002 , paired $t$ test). Overall, nitrate, phosphate and silicate concentrations also revealed distinct trends, decreasing seaward. However, silicate, ranging from 2.8 to $126.6 \mu \mathrm{M}$, had the highest correlation $(R=0.86, P<0.0001)$ with TSM. Ammonium and nitrite did not exhibit a gradient decreasing seaward, ranging from below detection limit to $1.68 \mu \mathrm{M}$ and from 0.05 to $1.33 \mu \mathrm{M}$, respectively. Detailed biogeochemical variables for each sampling point were showed in Table S2. For detailed figures on biogeochemical parameters, please refer to Hsiao et al. (2014).

\subsection{Phylogenetic diversity of the amoA and nirS gene clone libraries}

The analysis of the amoA gene clone libraries was carried out only at the sites in the salinity gradient for both the April and August cruises. Nineteen $\beta$-proteobacterial and 10 archaeal amoA gene clone libraries were constructed successfully. $\beta$-proteobacterial amoA gene in three surface samples from open water with the highest salinity values was not detected, while the archaeal amoA gene was not detected in most of the surface samples. The analysis of the nirS gene clone libraries was carried out only at the sites in the salinity gradient for the April cruise, and only four libraries from the bottom samples were constructed successfully. A total of $685 \beta$-proteobacterial and 386 archaeal amoA gene sequences and $338 \mathrm{nirS}$ gene sequences were recovered. Rarefaction analyses (at $95 \%$ DNA sequence identity) of each $\beta$-proteobacterial or archaeal amoA clone library indicated that these libraries might have encompassed the majority of the amoA sequence types in our sampling sites with the primers used (Fig. 2a). On the contrary, the diversity of each nirS clone library might have had higher nirS genotype diversity than recovered (Fig. 2b). The same conclusions were supported by the phylotype richness and diversity estimators (Table S1).

On the basis of phylogenetic analysis, all the $\beta$ proteobacterial amoA sequences fell in the Nitrosospira and Nitrosomonas clusters (Fig. 3). A total of 675 sequences from 


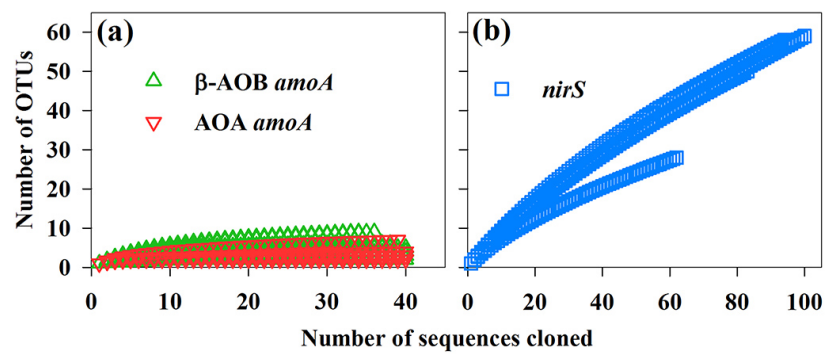

Fig. 2. Rarefaction analysis for the $\beta$-AOB and $\mathrm{AOA}$ amoA (a) and $\operatorname{nirS}$ (b) gene sequences. The curves were generated at $95 \%$ DNA sequence identity.

this study fell in the Nitrosospira cluster (612 sequences in Clade 1 and 63 sequences in Clade 2), while only 10 sequences from the closest-to-seashore site $\mathrm{Y0}$ (salinity $\sim 0.2$ ) in August fell in the Nitrosomonas cluster that is usually recovered from freshwater environments (Santoro, 2010). The sequences in Clade 1 of the Nitrosospira cluster had a 86 to $96 \%$ DNA sequence identity with the sequences recovered from Baltic Sea sediments (Kim et al., 2008), and Clade 2 had a 95 to $97 \%$ DNA sequence identity with sequences recovered from the Mediterranean sponge Aplysina aerophoba (Bayer et al., 2008). The Nitrosomonas cluster included mainly $\beta$-proteobacterial amoA sequences that had their closest-matched sequences recovered from Baltic Sea water (Kim et al., 2008) and Nitrosomonas sp. JL21. All archaeal amoA sequences fell in the previously described sediments (160 sequences), water column A from the Black Sea and Monterey Bay (225 sequences), and water column B from the eastern tropical North Pacific (one sequence) clusters (Francis et al., 2005) (Fig. 4). In general, the sequences recovered from the inshore sites with high TSM concentrations (sites $\mathrm{Y} 0$ and $\mathrm{Y} 3$ in August) fell in the sediments cluster, except for the AugY0BP sample (the particle-associated sample from the bottom of site Y0 in August), while the sequences recovered from the sites with low TSM concentrations (site Y5 in August; sites Y3, Y4 and Y5 in April) fell in the water column A cluster (Fig. 4).

NirS-type denitrifying bacteria are phylogenetically diverse. The phylogenetic tree grouped all nirS sequences into five clusters identified by Dang et al. (2009). The nirS sequences were predominantly $(77.3 \%)$ affiliated within marine cluster I, and occasionally within clusters II, IV, V and VII (Fig. 5). The sequences in marine clusters I, IV, V and VII had a 78 to $100 \%$ protein sequence identity with the sequences mainly recovered from various sedimentary environments (Braker et al., 2000; Nogales et al., 2002; Liu et al., 2003; Santoro et al., 2006; Tiquia et al., 2006; Falk et al., 2007; Ruiz-Rueda et al., 2007; Dang et al., 2009; Abell et al., 2010; Mosier and Francis, 2010), while the sequences in marine cluster II had a high protein sequence identity with the sequences recovered from estuarine and coastal sediments and waters (Nogales et al., 2002; Jayakumar et al., 2004;
Castro-González et al., 2005; Hannig et al., 2006; Santoro et al., 2006).

\subsection{Spatial structure of nitrifying and denitrifying microbial communities}

Clustering analysis based on NMDS ordination and one-way ANOSIM analysis showed that there were no significance differences in community structure between AOB communities (Fig. 6a). However, AOA communities significantly separated into two or three clusters. One cluster contained communities from the inshore sites (sites $\mathrm{Y} 0$ and $\mathrm{Y} 3$ in August) with the exception of AugY0BP, which was in the other cluster containing communities from the sites with low TSM concentrations (site Y5 in August; sites Y3, Y4 and Y5 in April) (Fig. 6b). This cluster pattern was consistent with the phylogenetic analysis of the archaeal amoA gene. Moreover, AOA communities in the low TSM cluster further separated into the free-living and particle-associated sub-clusters. Although an obvious separation between the nirS clone libraries could be observed in the NMDS ordination (Fig. 6c), there were no statistically significant differences in community composition using ANOSIM analysis due to the insufficiently large sample number.

\subsection{Spatio-temporal variation in amoA and nirS gene abundances}

QPCR quantification was performed for all fifty samples in April and August (Figs. 7 and 8). $\beta$-proteobacterial amoA gene abundance varied ranging from below detection limit to $1.56 \times 10^{6}$ copies $\mathrm{L}^{-1}$ in August and from $5.30 \times 10^{2}$ to $1.15 \times 10^{5}$ copies L $^{-1}$ in April. Archaeal amoA gene abundance varied ranging from $6.38 \times 10^{3}$ to $1.72 \times 10^{8}$ copies $\mathrm{L}^{-1}$ in August and from below detection limit to $6.66 \times 10^{5}$ copies $\mathrm{L}^{-1}$ in April. The archaeal amoA gene was significantly more abundant than the $\beta$ proteobacterial amoA gene $(P=0.001$, both paired and unpaired $t$ test). NirS gene abundance varied ranging from $7.54 \times 10^{3}$ to $1.85 \times 10^{5}$ copies $\mathrm{L}^{-1}$ in April and from $1.59 \times 10^{4}$ to $1.02 \times 10^{8}$ copies $\mathrm{L}^{-1}$ in August. In general, abundance of nirS genes was significantly lower than that of total amoA genes $(P=0.001$, paired $t$ test; $P=0.006$, unpaired $t$ test). All three gene abundances were significantly higher in the bottom waters than those in the surface communities $(P=0.000,0.000$ and 0.041 for $\beta$-proteobacterial amoA, archaeal amoA and nirS genes, respectively, unpaired $t$ test). Moreover, archaeal amoA and nirS gene abundances of free-living communities in August, when DO concentrations were significantly lower than those in April $(P=$ 0.000 , unpaired $t$ test), outnumbered those in April $(P=$ 0.019 and 0.000 , respectively, unpaired $t$ test) (Fig. 7).

In the salinity transect, $\beta$-proteobacterial amo $A$ gene abundance generally decreased with increasing salinity in $\mathrm{Au}-$ gust, especially for the particle-associated samples (Fig. 8a 


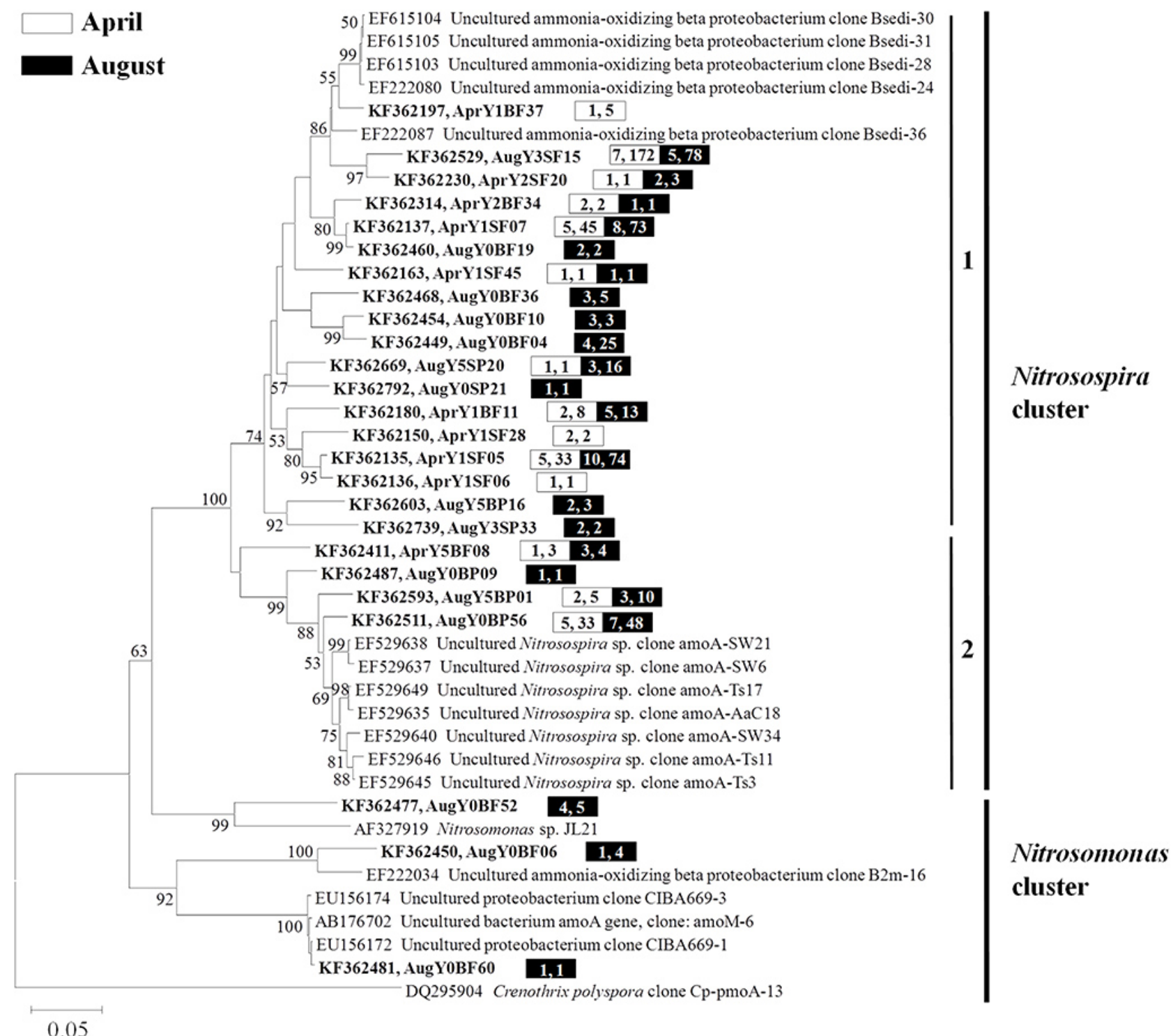

Fig. 3. Phylogenetic tree of $\beta$-AOB amoA constructed based on DNA sequences using the neighbor-joining method. Sequences from this study are shown in bold, and sequences sharing $95 \%$ DNA identity are grouped. In these groups, the number of samples and sequences is shown in the frame. GenBank accession numbers are shown. Phylogenetic relationships were bootstrapped 1000 times, and bootstrap values greater than $50 \%$ were shown. Scale bar represents the nucleotide substitution percentage.

and b). However, such a trend was not observed for the archaeal amoA gene and the highest abundance was found in the free-living community at the bottom of the offshore site Y4 in August (Fig. 7b). The highest abundance of the nirS gene was detected in the particle-associated sample from the bottom of site Y3 in August where and when DO was lowest in this salinity transect. Notably, the abundances of particleassociated $\beta$-proteobacterial amoA, archaeal amoA and nirS genes were higher than the free-living ones at the closestto-seashore site Y0 $(P<0.05$ for each unpaired $t$ test $)$ and at the bottom of site Y3 $(P=0.028,0.010$ and 0.001 , respectively, unpaired $t$ test), where TSM concentrations were highest among all particle size-selective sampling sites. On the contrary, the three gene abundances of particle-associated samples were generally lower than the free-living ones at the most distant offshore site Y5, with the exception of the nirS gene in the bottom water ( $P<0.05$ for each unpaired $t$ test) (Fig. 8a and b). The ${ }^{15} \mathrm{~N}$-based nitrification rates supported these findings. Higher rates were detected in the particleassociated samples than the free-living ones at the sampling points with high TMS concentrations (Hsiao et al., 2014). Also, the significant positive correlations $(P<0.05)$ were observed between the ratios of particle-associated vs. freeliving amoA gene copy numbers and the ratios of ${ }^{15} \mathrm{~N}$-based 


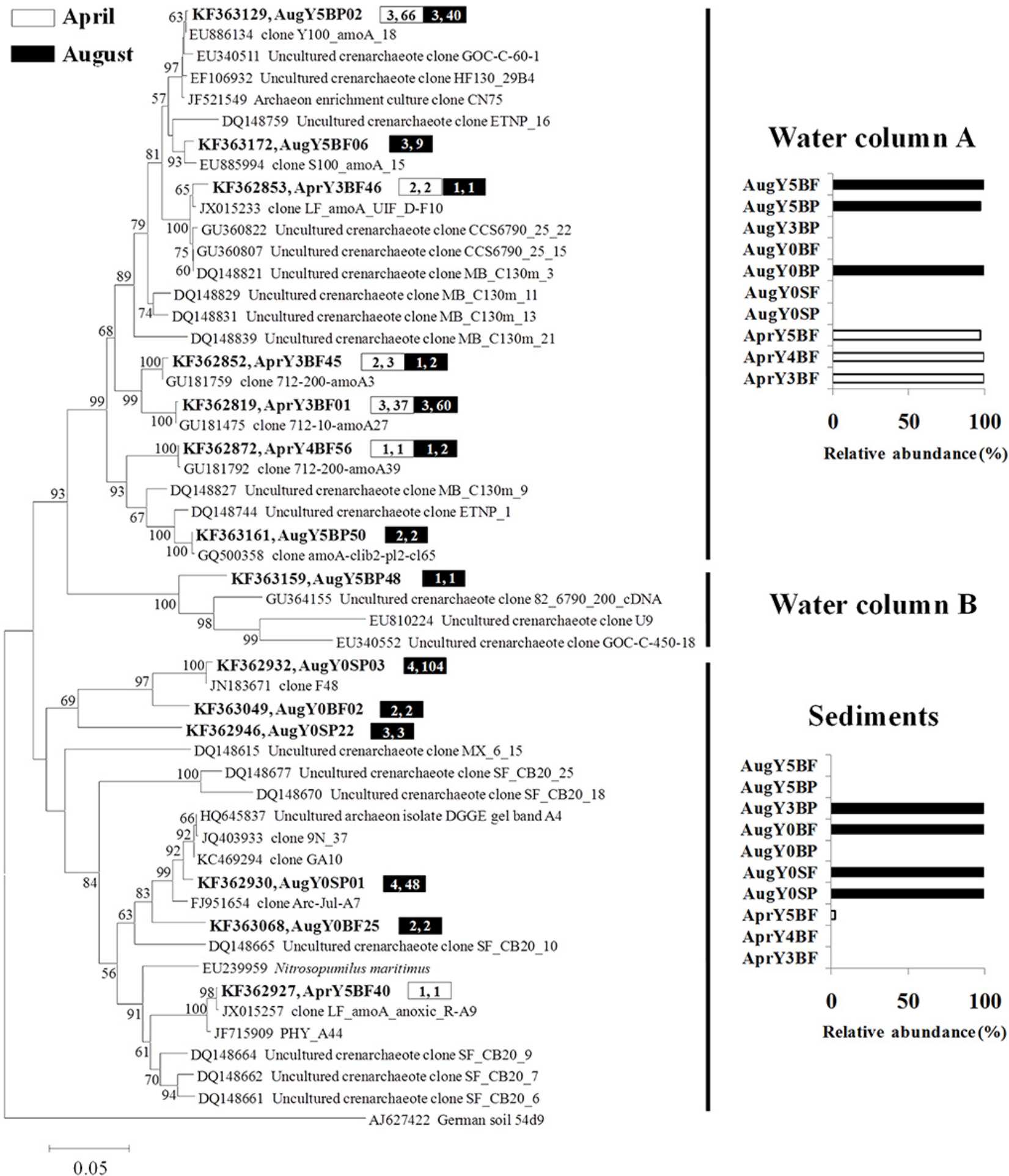

Fig. 4. Phylogenetic tree of AOA amoA constructed based on DNA sequences using the neighbor-joining method. Sequences from this study are shown in bold, and sequences sharing $95 \%$ DNA identity are grouped. In these groups, the number of samples and sequences is shown in the frame. The relative abundance of clones retrieved for each clone library in the three clusters is indicated by the bar. GenBank accession numbers are shown. Phylogenetic relationships were bootstrapped 1000 times, and bootstrap values greater than $50 \%$ were shown. Scale bar represents the nucleotide substitution percentage. 


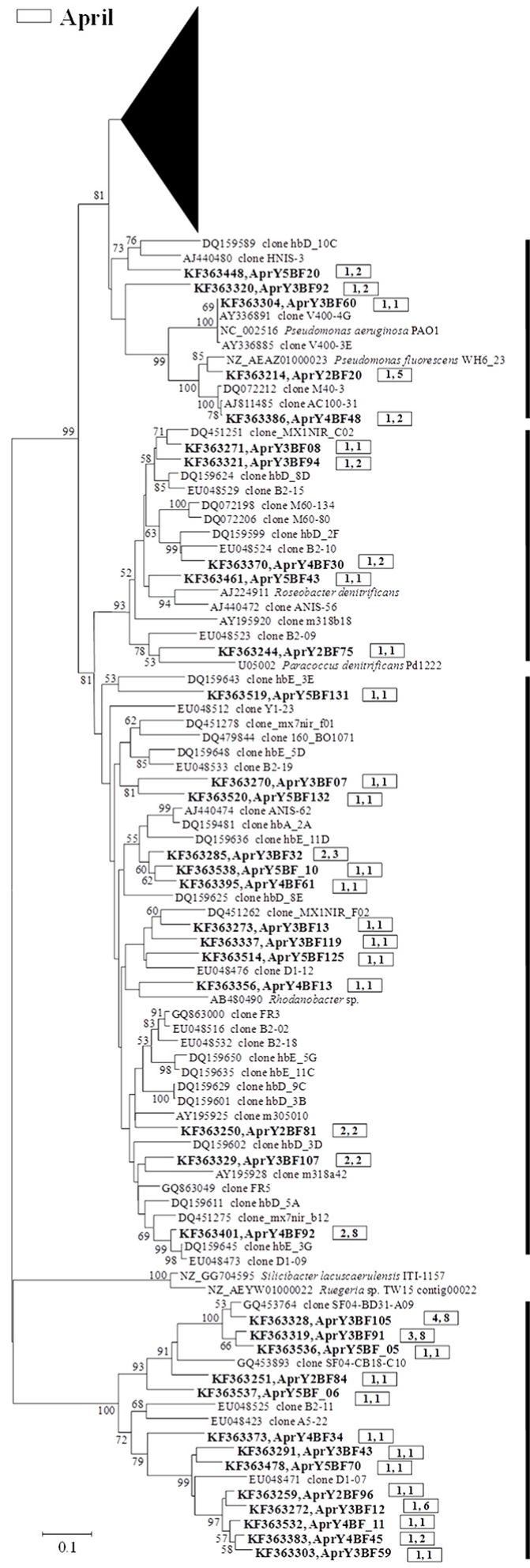

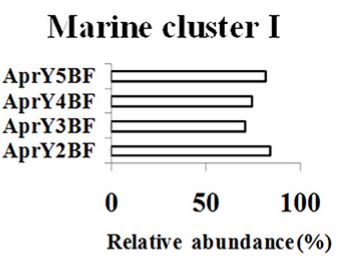

\section{Marine cluster II}

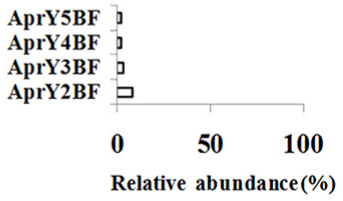

\section{Marine cluster $\mathbf{V}$}

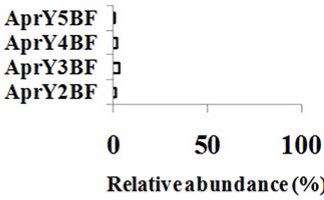

Marine cluster IV

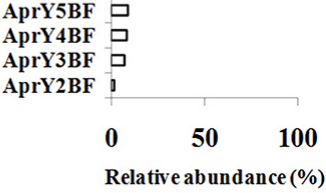

Marine cluster VII

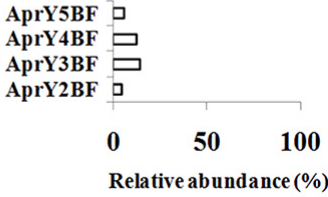

Relative abundance (\%)

Fig. 5. Phylogenetic tree of nirS constructed based on amino acid sequences using the neighbor-joining method. Sequences from this study are shown in bold, and sequences sharing $95 \%$ DNA identity are grouped. In these groups, the number of samples and sequences is shown in the frame. The relative abundance of clones retrieved for each clone library in the five clusters is indicated by the bar. GenBank accession numbers are shown. Phylogenetic relationships were bootstrapped 1000 times, and bootstrap values greater than $50 \%$ were shown. Scale bar represents the amino acid substitution percentage. 

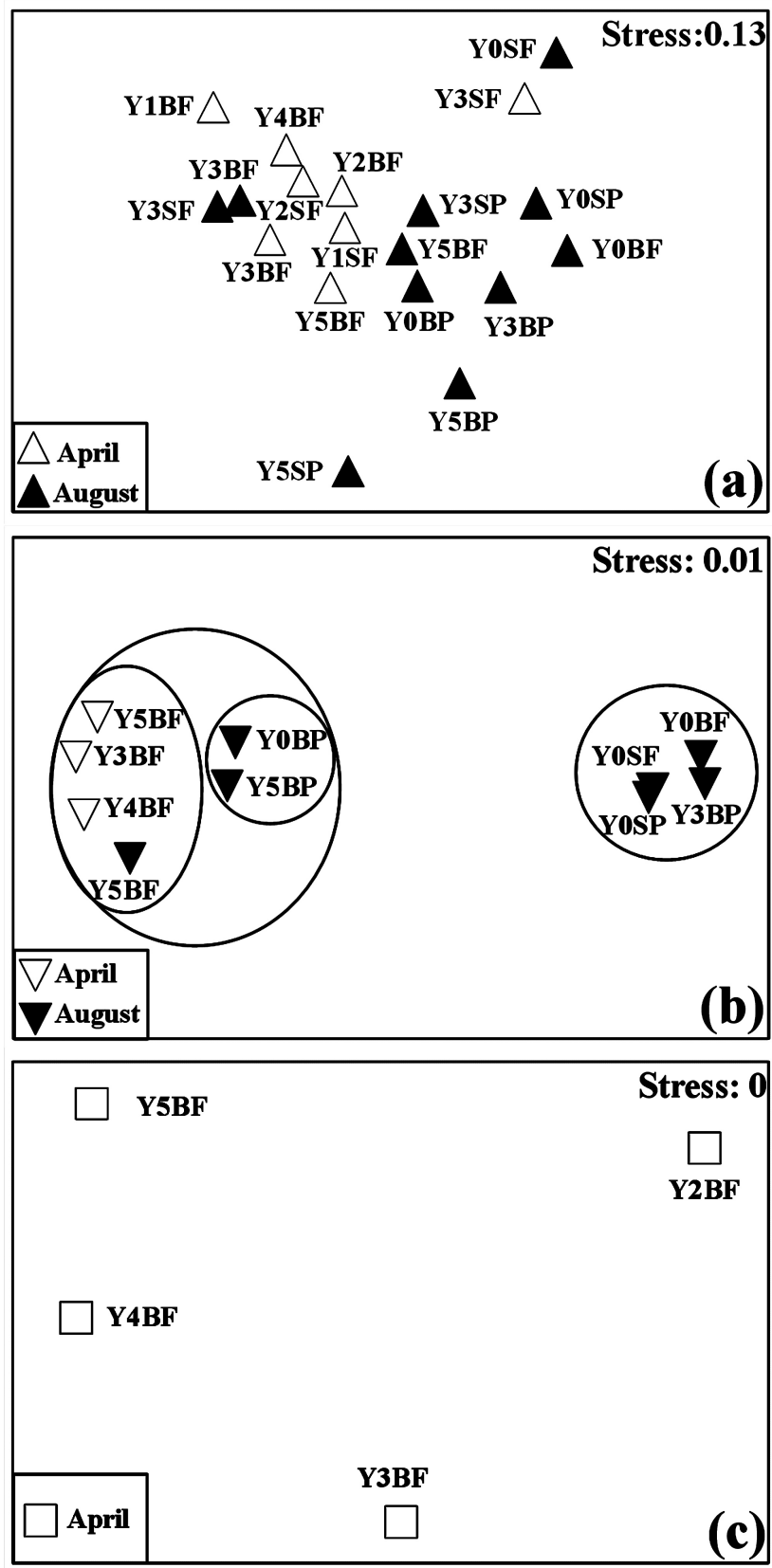

Fig. 6. NMDS ordination based on Bray-Curtis similarities between $\beta$-AOB amoA-type nitrifying (a), AOA amoA-type nitrifying (b) or nirS-type denitrifying communities (c). Each symbol represents an individual sample in the NMDS charts.

nitrification rates (Fig. 9) despite no direct correlations between rates and gene copies. In the latitude transect, however, $\beta$-proteobacterial amoA, archaeal amoA and nirS genes from the free-living communities mostly outnumbered those in the particle-associated fraction, especially for the surface samples $(P=0.001,0.001$ and 0.000 , respectively, unpaired $t$ test) (Fig. 7c and d). This was consistent with the lower TSM concentrations in the latitude $\left(2.5-60.9 \mathrm{mg} \mathrm{L}^{-1}\right)$ rather

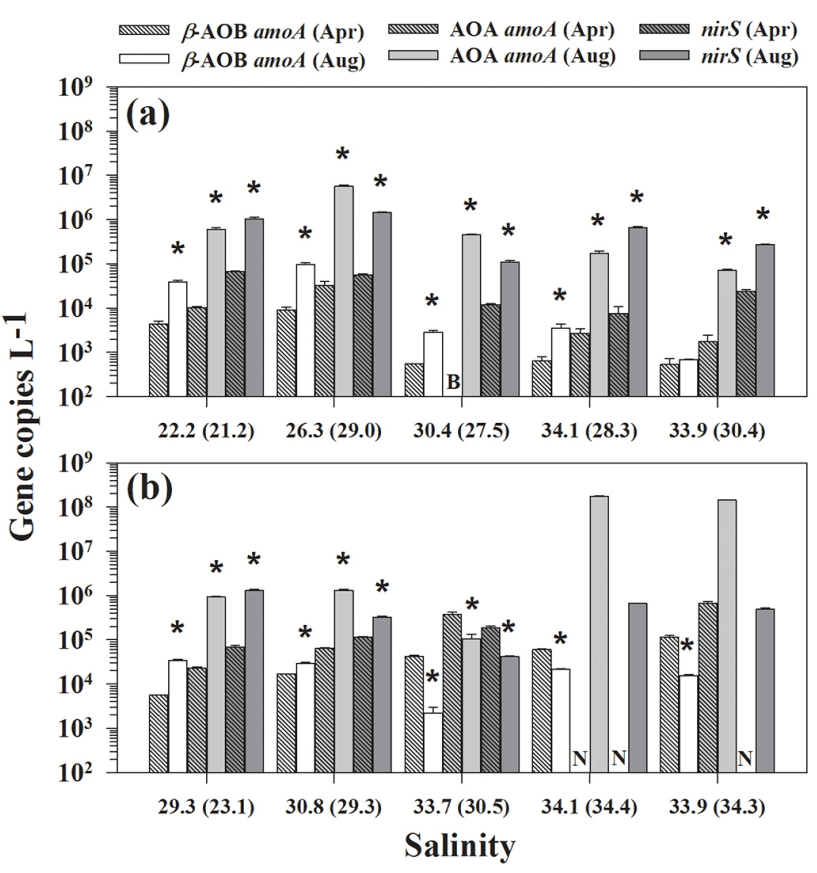

Fig. 7. $\beta$-AOB and AOA amoA and nirS gene abundances from the free-living $(0.2 \sim 3 \mu \mathrm{m})$ communities along the salinity transect in April and August (between parentheses). Error bars indicate standard deviation. Asterisks indicate statistically significant differences between the April and August samples. (a) and (b) represent the surface and bottom samples. B: below detection limit; N: not detected due to lack of enough environmental DNA.

than the salinity transects $\left(3.4-261.8 \mathrm{mg} \mathrm{L}^{-1}\right)(P=0.026$, unpaired $t$ test). Notably, a significant positive relationship between total amoA (sum of $\beta$-AOB and AOA amoA) and nir $S$ gene abundance was observed $(P<0.01)$, which was in fact mainly contributed by the significant positive correlation of particle-associated total amoA with nirS gene abundance $(P<0.01)$ (Fig. 10).

\subsection{Key environmental factors revealed by statistical analysis}

RDA analysis illustrating correlations between the community structure and environmental factors revealed that silicate concentration was the only statistically significant variable explaining the free-living AOB communities cluster pattern $(P=0.001)$, and the first axes in the RDA model explained $100 \%$ of the cumulative variance of the bacterial amoA-environment relationship (Fig. 11a). In the RDA model based on the archaeal amoA gene, silicate and DO concentrations emerged as highly significant explanatory variables for the spatial structure of the free-living AOA communities $(P=0.001)$, and the first and second axes explained 97.4 and $2.6 \%$ of the cumulative variance of the archaeal amoA-environment relationship (Fig. 11b). However, for the particle-associated AOA and AOB communities, no 


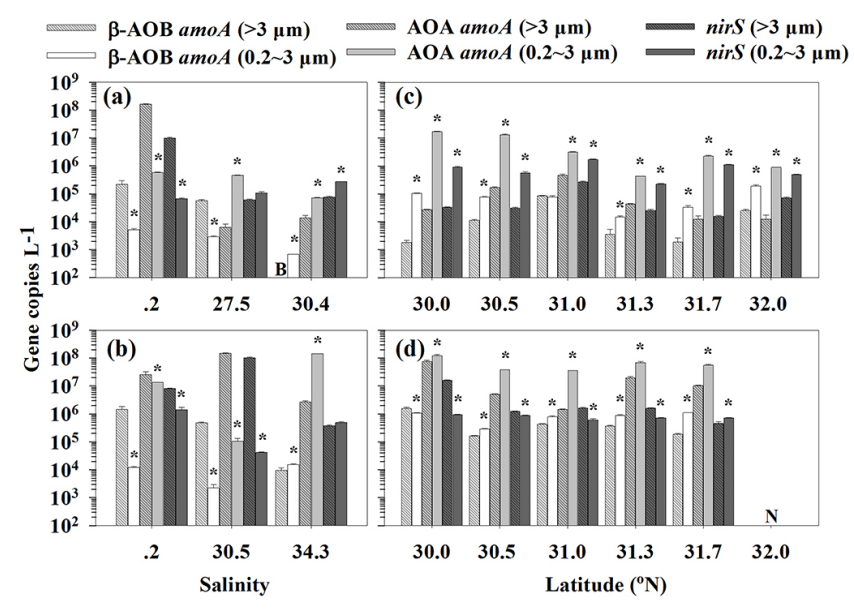

Fig. 8. $\beta$-AOB and AOA amoA and nirS gene abundances from the particle-associated $(>3 \mu \mathrm{m})$ and free-living $(0.2 \sim 3 \mu \mathrm{m})$ communities in the salinity and latitude transects. Error bars indicate standard deviation. Asterisks indicate statistically significant differences between the particle-associated and free-living samples. (a) and (b) represent the surface and bottom samples of sites Y0, Y3 and Y5 along the salinity transect. (c) and (d) represent the surface and bottom samples of sites YE5, YE4, YE3, YE2, YE1 and YE0 along the latitude transect. B: below detection limit; N: not detected due to lack of enough environmental DNA.

statistically significant environmental factors were obtained in CCA or RDA analysis with all available variables. Also, no significant environmental variables were found in the nirS gene-based CCA or RDA analysis, likely owing to an insufficiently large sample size (only four).

Analysis of relationships between gene abundances and environmental factors revealed significant negative relationships between AOA $(R=0.37, P<0.01)$ or $\beta$-AOB amoA gene abundance $(R=0.53, P<0.01)$ and DO concentration. Furthermore, for the free-living assemblages, statistically significant negative relationships were observed between $\beta$-proteobacterial amoA $(R=0.76, P<0.01)$, archaeal amoA $(R=0.59, P<0.01)$ or $\operatorname{nir} S$ gene abundance $(R=0.48, P<0.01)$ and DO concentration. No significant relationships were found between the particle-associated gene abundances and the presently investigated variables. Nevertheless, there are statistically significant positive relationships between the percentage of particle-associated in total $\beta$-proteobacterial amoA $(R=0.63, P<0.01)$, archaeal amoA $(R=0.81, P<0.01)$ or nirS gene abundance $(R=$ $0.80, P<0.01)$ and TSM concentration $(P<0.01$ for each $)$.

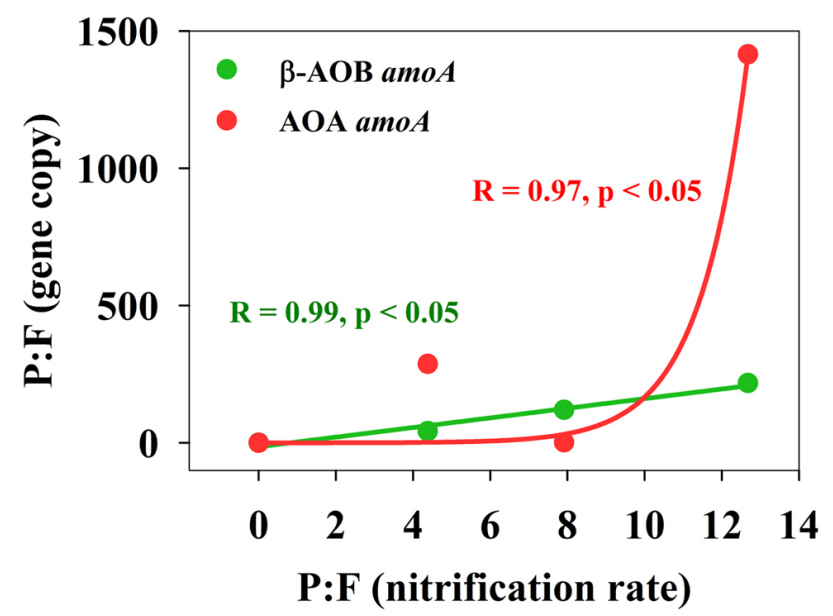

Fig. 9. Correlations between the ratios of particle-associated vs. free-living amoA gene copy numbers and the ratios of ${ }^{15} \mathrm{~N}$-based nitrification rates.

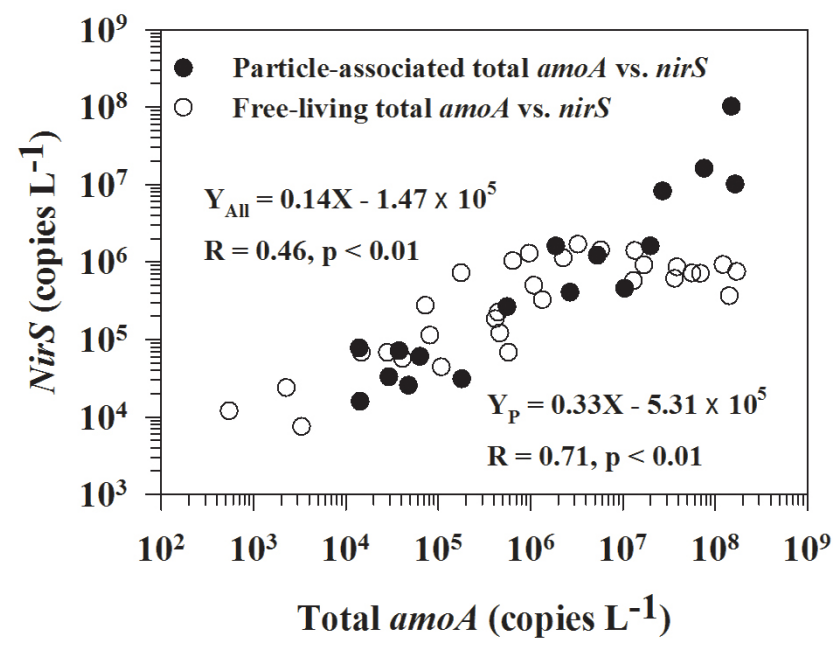

Fig. 10. Analysis of relationships between the total amoA (sum of $\beta$-AOB and AOA amoA) and nirS gene abundances.

\section{Discussion}

\subsection{Higher potentials for both nitrification and denitrification in bottom than surface water}

All nirS and most of the archaeal amoA gene sequences in this study were recovered from the bottom water using PCR and the clone library method. Moreover, QPCR quantification revealed significantly higher $\beta$-proteobacterial and archaeal amoA and nirS gene abundances in the bottom than those in the surface water. These suggested that compared to the surface water, the bottom water might be more favorable for both nitrification and denitrification potentials, where DO concentrations were significantly lower than those at the surface ( $P=0.000$, paired $t$ test $)$ and TSM concentrations were 

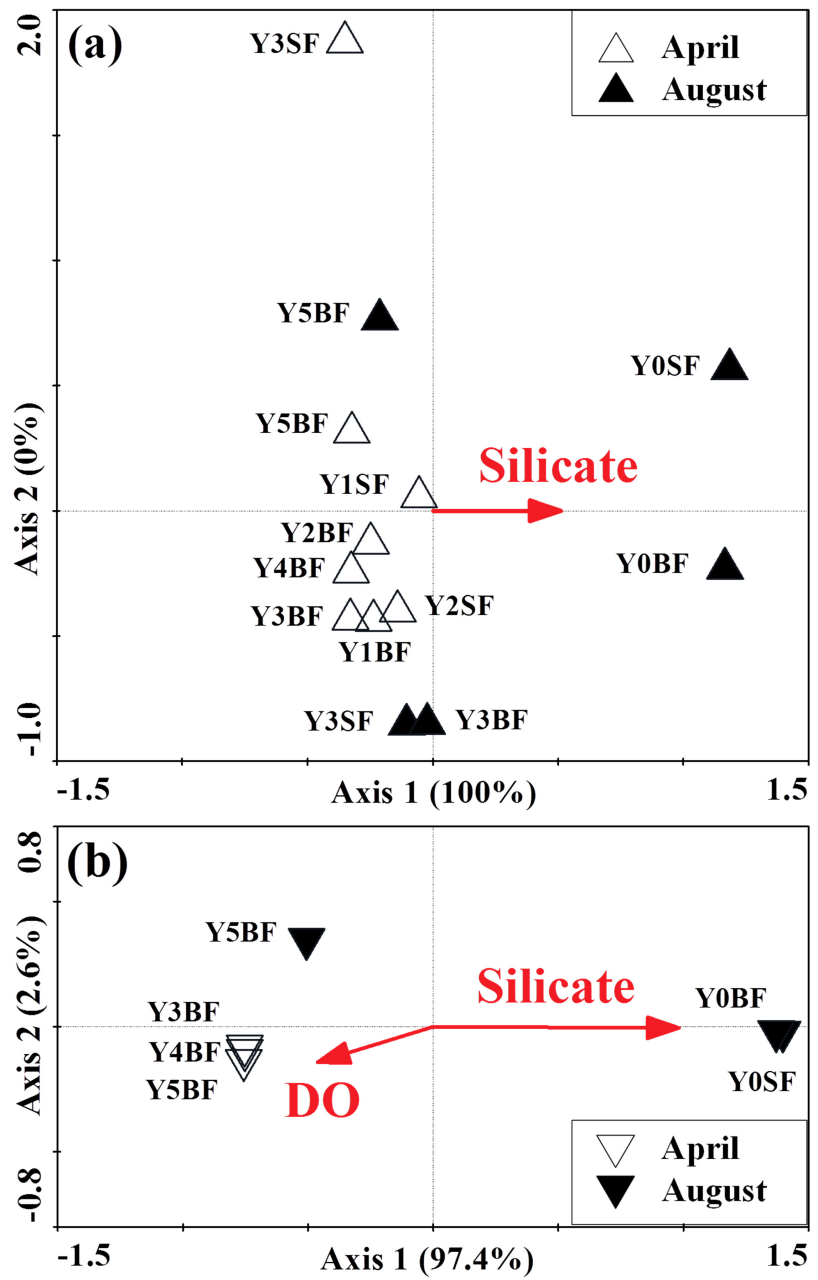

Fig. 11. RDA analysis of free-living $\beta$-AOB (a) and AOA amoAtype (b) nitrifying communities. Each symbol represents an individual sample. Arrows represent statistically significant environment factors explaining the observed patterns $(P=0.001)$. DO: dissolved oxygen.

significantly higher $(P=0.002$, paired $t$ test). Thus, higher gene abundances in the bottom water might be a consequence of benefiting from environmental conditions of low DO and high TSM concentrations or simply caused by mix of gene from sediment, as revealed by our phylogenetic analysis. On the other hand, living phytoplankton in the surface water may compete for nutrients with nitrifiers and denitrifiers, such as ammonia and oxidized $\mathrm{N}$ forms, and nitrifiers are likely photoinhibited (Merbt et al., 2012), thus resulting in low potentials for both nitrification and denitrification.

\subsection{Higher potentials for both nitrification and denitrification in particle-associated rather than free-living assemblages}

Although phylogenetic analysis did not show distinct differences in amoA-type nitrifying and nirS-type denitrifying microbial communities between the particle-associated and free-living assemblages, clustering analysis based on NMDS ordination suggested that AOA communities might be influenced by suspended particles since they significantly separated into the free-living and particle-associated sub-clusters in the cluster of offshore sites (Fig. 6). Furthermore, qPCR quantification revealed significantly higher $\beta$-proteobacterial and archaeal amoA and nirS gene abundances in the particleassociated than in the free-living communities at the sites with high TSM concentrations in the river mouth. This finding was supported by ${ }^{15} \mathrm{~N}$-based nitrification rates (Hsiao et al., 2014) and the significant positive correlations $(P<0.05)$ between the ratios of particle-associated vs. free-living amoA gene copy numbers and the ratios of ${ }^{15} \mathrm{~N}$-based nitrification rates (Fig. 9). We speculated that the microniche of suspended particulates could be beneficial to microbial activity. Microorganisms can take advantage of the vicinal supply of nutrients from particles, e.g., ammonia for nitrifiers (Belser, 1979; Crump et al., 1998; Xia et al., 2009). Organic particles may also serve as a direct substrate for AOA, since some Thaumarchaeota possess the ability to utilize amino acids heterotrophically (Ouverney and Fuhrman, 2000; Teira et al., 2006). In addition, the lower oxygen availability in the microniche of particles was favorable for both nitrification and denitrification potentials in oxygenated water column (Hanaki et al., 1990; Kester et al., 1997). Thus, it is suggested that higher potentials for both nitrification and denitrification might occur on the particles rather than in the water column.

\subsection{Higher nitrification than denitrification potential}

Phylogenetic analysis revealed that AOA communities were dominated by sediments and water column A clusters of $\mathrm{Cre}$ narchaeota, whereas the nirS sequences were much more diverse than the amoA gene and closely affiliated with the sequences recovered mainly from a wide range of estuarine sediments. A similar difference between the amoA and nirS gene diversity is also reported in the study from the Fitzroy estuary sediments in central Queensland (Abell et al., 2010). Although high levels of diversity were observed in the YRE, the nirS gene abundance was significantly lower than that of total $a m o A$ gene in the YRE $(P=0.006$, unpaired $t$ test; $P=0.001$, paired $t$ test). This was supported by the ${ }^{15} \mathrm{~N}-$ based nitrification and denitrification rate data as the denitrification rate was below the method detection limit. Taken together, ${ }^{15} \mathrm{~N}$-based rate and gene abundances suggested that the denitrification potential was lower than nitrification potential in the YRE. Denitrifiers are reported to be often capable of several different respiratory pathways, including 
oxygen respiration (Santoro, 2010). Thus, we speculated that diverse denitrifiers were not actively conducting denitrification in the YRE water; instead, heterotrophic metabolism with $\mathrm{O}_{2}$ respiration is more likely, since DO concentrations were not low enough during our cruise periods.

Notably, the qPCR analysis showed that the abundance of the archaeal amoA gene was significantly higher than that of the $\beta$-proteobacterial amoA gene ( $P=0.001$, both unpaired and paired $t$ test). Similarly, an overwhelming dominance of AOA over AOB has been observed in various terrestrial and aquatic environments (Leininger et al., 2006; Wuchter et al., 2006; Caffrey et al., 2007; Lam et al., 2007; Mincer et al., 2007; Beman et al., 2008; Shen et al., 2008; De Corte et al., 2009; Abell et al., 2010; Beman et al., 2010; Santoro et al., 2010) with a few studies reporting a greater contribution of AOB than AOA in some estuarine environments with unlimited ammonia supply (Santoro et al., 2008; Wankel et al., 2011). Also, ${ }^{15} \mathrm{NH}_{4}^{+}$oxidation rates are often reported to be intimately correlated with $\mathrm{AOA}$ rather than $\mathrm{AOB}$ amoA gene abundance in various marine environments (Caffrey et al., 2007; Beman et al., 2008). The dominance of AOA in amoAtype nitrifiers may be due to their high affinity for ammonia (Martens-Habbena et al., 2009; Stahl and de la Torre, 2012) and thus AOA are considered to be more competitive in environments with low ammonia levels (Martens-Habbena et al., 2009), such as the water studied here (below the detection limit to $1.68 \mu \mathrm{M})$.

\subsection{Potential coupling between nitrification and denitrification}

The significant positive relationship between total $a m o A$ and nirS gene abundance $(P<0.01)$ was mainly contributed by the particle-associated samples $(P<0.01)$ (Fig. 10), suggesting higher potential coupling between ammonia oxidization and denitrification on particles rather than in water column. Although the denitrification rate was below the method detection limit throughout our survey, such gene-based coupling hinted that it might make sense under the appropriate environmental conditions. Similarly, the tight coupling between both processes has been observed by using ${ }^{15} \mathrm{~N}$ incubation or gene analysis methods at the oxic-anoxic interfaces, such as the sediment-water interface, bacteria-algae mats and the oxic-anoxic transition zone of sediments or water columns (Jenkins and Kemp, 1984; Rysgaard et al., 1993; Jensen et al., 1994; Risgaard-Petersen et al., 1994; Ward, 1996). Although we cannot provide concrete evidence of the biochemical linkage of the potential coupling, we speculated that nitrifying and denitrifying processes provided directly or indirectly reactants for each other. For example, $\mathrm{NO}_{2}^{-}$produced from ammonia oxidization might serve as a direct reactant for nitrite reduction. Conversely, nitrite reduction provided NO for the $\mathrm{NO}_{\mathrm{x}}$ cycle (Schmidt et al., 2001; Kampschreur et al., 2006; Schmidt, 2008), from which $\mathrm{N}_{2} \mathrm{O}_{4}$ is produced and may potentially serve as an oxidant in am- monia oxidization (Lund et al., 2012). Therefore, a smaller spatial distance, such as the microniche of suspended particulates, is more favorable for both reactions to gain more reactants.

\subsection{Key environmental factors}

Silicate and DO concentrations were the statistically significant variables explaining the free-living $\mathrm{AOB}$ and $\mathrm{AOA}$ communities' cluster patterns $(P=0.001)$ in the RDA models (Fig. 11). Silicate is reported to be one of the most common indicators discriminating river water in the ocean (Moore, 1986) and was found to have the highest correlation with TSM $(R=0.86, P<0.0001)$ among all nutrients in our study area. Thus, it significantly contributed to formation of the spatial structure of communities in the estuary area. In an analysis of relationships between gene abundances and environmental factors, DO concentration emerged as a highly significant variable regulating the gene abundances from the free-living assemblages (negative correlations, $P<0.01$ for each). It is well known that denitrifiers favor low DO environments to conduct anaerobic respiration and AOA and AOB are highly abundant under low-oxygen conditions due to relatively high ammonia levels (Lam et al., 2007; Beman et al., 2008; Park et al., 2010; Yan et al., 2012). Our results support these consensuses. However, for the particle-associated AOA and AOB communities, no statistically significant environmental factors were obtained in CCA or RDA models and correlations analysis with all available variables. We speculated that the microniche of suspended particles might be responsible for the particle-associated community structure rather than water column properties. This speculation was further supported by the significant positive relationships between the percentage of particle-associated in total $\beta$-proteobacterial amoA, archaeal amoA or nirS gene abundance and TSM concentration $(P<0.01$ for each). Based on the above analysis, we speculated that once DO concentration matches the stoichiometric demands of both microbial denitrification and nitrification reactions in estuary areas where organic carbon and nutrients are not limiting and where TSM concentrations are high, the coupling between nitrification and denitrification would make a significant contribution to $\mathrm{N}$ removal and consequently reduce the eutrophication of the YRE.

\section{Summary}

This study provided the first hand data set concerning the diversity and distribution of amoA-type nitrifying and nirStype denitrifying microbial communities in an anthropogenically perturbed estuary with high turbidity. Our observations suggested that the estuary bottom might be more favorable for both nitrification and denitrification potentials than the surface water, and higher potentials might occur in the 
particle-associated rather than the free-living assemblages in the high-turbidity river mouth. However, compared with the low diversity but high nitrification potential of amoA-type nitrifiers, nirS-type denitrifiers exhibited a rather high diversity but low denitrification potential as supported by the ${ }^{15} \mathrm{~N}$ incubation experiments, suggesting that diverse denitrifiers might conduct other respiratory pathways such as oxygen respiration. Compared with the AOB, the abundance of AOA are dominant in amoA-type nitrifiers in the YRE. Notably, potential coupling between nitrification and denitrification were revealed by the functional gene abundances, which was in fact mainly contributed by the potential coupling between denitrification and AOA ammonia oxidization in the particleassociated assemblages. Statistical analysis revealed further that low DO and high TSM conditions favored amoA-type nitrifiers, nirS-type denitrifiers and the two processes coupling, which would significantly contribute to $\mathrm{N}$ removal and the reduction of eutrophication in the YRE once DO concentration matches the stoichiometric demands of both microbial denitrification and nitrification reactions.

\section{Supplementary material related to this article is available online at http://www.biogeosciences.net/11/ 2131/2014/bg-11-2131-2014-supplement.pdf.}

Acknowledgements. We thank Professor Minhan Dai, the chief scientist of the YRE project, for providing the sampling opportunity and the temperature, salinity, DO, TSM and nutrient data. We also thank Jinwen Liu, Hongjie Wang and Tao Huang for their assistance in sampling and sample analysis, and Professor John Hodgkiss for his help with English. This research was funded by 973 program 2013CB955700, NSFC projects 41176095, 91028001, 41121091 and 41023007, OPWSR project 201105021, projects GASI-03-01-02-03 and GASI-03-01-02-05.

Edited by: H. Thomas

\section{References}

Abell, G. C. J., Revill, A. T., Smith, C., Bissett, A. P., Volkman, J. K., and Robert, S. S.: Archaeal ammonia oxidizers and nirS-type denitrifiers dominate sediment nitrifying and denitrifying populations in a subtropical macrotidal estuary, ISME J., 4, 286-300, 2010.

Bayer, K., Schmitt, S., and Hentschel, U.: Physiology, phylogeny and in situ evidence for bacterial and archaeal nitrifiers in the marine sponge Aplysina aerophoba, Environ. Microbiol., 10, 29422955, 2008.

Belser, L. W.: Population ecology of nitrifying bacteria, Annu. Rev. Microbiol., 33, 309-333, 1979.

Beman, J. M., Popp, B. N., and Francis, C. A.: Molecular and biogeochemical evidence for ammonia oxidation by marine Crenarchaeota in the Gulf of California, ISME J., 2, 429-441, 2008.
Beman, J. M., Sachdeva, R., and Fuhrman, J. A.: Population ecology of nitrifying Archaea and Bacteria in the Southern California Bight, Environ. Microbiol., 12, 1282-1292, 2010.

Bothe, H., Jost, G., Schloter, M., Ward, B. B., and Witzel, K.P.: Molecular analysis of ammonia oxidation and denitrification in natural environments, FEMS Microbiol. Rev., 24, 673-690, 2000.

Braker, G., Fesefeldt, A., and Witzel, K.-P.: Development of PCR primer systems for amplification of nitrite reductase genes (nirK and nirS) to detect denitrifying bacteria in environmental samples, Appl. Environ. Microbiol., 64, 3769-3775, 1998.

Braker, G., Zhou, J., Wu, L., Devol, A. H., and Tiedje, J. M.: Nitrite reductase genes (nirK and nirS) as functional markers to investigate diversity of denitrifying bacteria in Pacific Northwest marine sediment communities, Appl. Environ. Microbiol., 66, 2096-2104, 2000.

Caffrey, J. M., Bano, N., Kalanetra, K., and Hollibaugh, J. T.: Ammonia oxidation and ammonia-oxidizing bacteria and archaea from estuaries with differing histories of hypoxia, ISME J., 1, 660-662, 2007.

Castro- González, M., Braker, G., Farías, L., and Ulloa, O.: Communities of nirS-type denitrifiers in the water column of the oxygen minimum zone in the eastern South Pacific, Environ. Microbiol., 7, 1298-1306, 2005.

Clarke, K. R.: Non-parametric multivariate analyses of changes in community structure, Aust. J. Ecol., 18, 117-143, 1993.

Clarke, K. R. and Gorley, R. N.: PRIMER v5: User manual/tutorial, PRIMER-E, Plymouth UK, 91 pp., 2001.

Coyne, M. S., Arunakumari, A., Averill, B. A., and Tiedje, J. M. Immunological identification and distribution of dissimilatory heme cd1 and non-heme copper nitrite reductases in denitrifying bacteria, Appl. Environ. Microbiol., 55, 2924-2931, 1989.

Crump, B. C., Baross, J. A., and Simenstad, C. A.: Dominance of particle-attached bacteria in the Columbia River estuary, USA, Aquat. Microb. Ecol., 14, 7-18, 1998.

Dai, Z. J., Du, J. Z., Zhang, X. L., Su, N., and Li, J. F.: Variation of riverine material loads and environmental consequences on the Changjiang (Yangtze) Estuary in recent decades (1955-2008), Environ. Sci. Technol., 45, 223-227, 2011.

Dang, H., Wang, C., Li, J., Li, T., Tian, F., Jin, W., Ding, Y., and Zhang, Z.: Diversity and distribution of sediment nirS-encoding bacterial assemblages in response to environmental gradients in the eutrophied Jiaozhou Bay, China, Microb. Ecol., 58, 161-169, 2009.

De Corte, D., Yokokawa, T., Varela, M. M., Agogué, H., and Herndl, G. J.: Spatial distribution of Bacteria and Archaea and amoA gene copy numbers throughout the water column of the Eastern Mediterranean Sea, ISME J., 3, 147-158, 2009.

Falk, S., Hannig, M., Gliesche, C., Wardenga, R., Köster, M., Jürgens, K., and Braker, G.: nirS-containing denitrifier communities in the water column and sediment of the Baltic Sea, Biogeosciences, 4, 255-268, doi:10.5194/bg-4-255-2007, 2007.

Francis, C. A., Roberts, K. J., Beman, J. M., Santoro, A. E., and Oakley, B. B.: Ubiquity and diversity of ammonia-oxidizing archaea in water columns and sediments of the ocean, P. Natl. Acad. Sci. USA, 102, 14683-14688, 2005.

Hanaki, K., Wantawin, C., and Ohgaki, S.: Nitrification at low levels of dissolved oxygen with and without organic loading in a suspended-growth reactor, Water Res., 24, 297-302, 1990. 
Hannig, M., Braker, G., Dippner, J., and Jürgens, K.: Linking denitrifier community structure and prevalent biogeochemical parameters in the pelagial of the central Baltic Proper (Baltic Sea), FEMS Microbiol. Ecol., 57, 260-271, 2006.

Hu, A., Yao, T., Jiao, N., Liu, Y., Yang, Z., and Liu, X.: Community structures of ammonia-oxidising archaea and bacteria in highaltitude lakes on the Tibetan Plateau, Freshwater Biol., 55, 23752390, 2010.

$\mathrm{Hu}$, A., Jiao, N., and Zhang, C. L.: Community structure and function of planktonic Crenarchaeota: changes with depth in the South China Sea, Microb. Ecol., 62, 549-563, 2011.

Huang, S., Chen, C., Yang, X., Wu, Q., and Zhang, R.: Distribution of typical denitrifying functional genes and diversity of the nirS-encoding bacterial community related to environmental characteristics of river sediments, Biogeosciences, 8, 30413051, doi:10.5194/bg-8-3041-2011, 2011.

Hsiao, S. S.-Y., Hsu, T.-C., Liu, J.-w., Xie, X., Zhang, Y., Lin, J., Wang, H., Yang, J.-Y. T., Hsu, S.-C., Dai, M., and Kao, S.-J.: Nitrification and its oxygen consumption along the turbid Chang Jiang River plume, Biogeosciences, 11, 2083-2098, doi:10.5194/bg-11-2083-2014, 2014.

Hsu, T.-C. and Kao, S.-J.: Technical Note: Simultaneous measurement of sedimentary $\mathrm{N}_{2}$ and $\mathrm{N}_{2} \mathrm{O}$ production and a modified ${ }^{15} \mathrm{~N}$ isotope pairing technique, Biogeosciences, 10, 7847-7862, doi:10.5194/bg-10-7847-2013, 2013.

Jayakumar, D. A., Francis, C. A., Naqvi, S. W. A., and Ward, B. B.: Diversity of nitrite reductase genes $(n i r S)$ in the denitrifying water column of the coastal Arabian Sea, Aquat. Microb. Ecol., 34, 69-78, 2004.

Jenkins, M. C. and Kemp, W. M.: The coupling of nitrification and denitrification in two estuarine sediments, Limnol. Oceanogr., 29, 609-619, 1984.

Jensen, K., Sloth, N. P., Risgaard-Petersen, N., Rysgaard, S., and Revsbech, N. P.: Estimation of nitrification and denitrification from microprofiles of oxygen and nitrate in model sediment systems, Appl. Environ. Microbiol., 60, 2094-2100, 1994

Kampschreur, M. J., Tan, N. C. G., Picioreanu, C., Jetten, M. S. M., Schmidt, I., and van Loosdrecht, M. C. M.: Role of nitrogen oxides in the metabolism of ammonia-oxidizing bacteria, Biochem. Soc. T., 34, 179-181, 2006.

Kester, R. A., de Boer, W.., and Laanbroek, H. J.: Production of NO and $\mathrm{N}_{2} \mathrm{O}$ by pure cultures of nitrifying and denitrifying bacteria during changes in aeration, Appl. Environ. Microbiol., 63, 38723877, 1997.

Kim, O.-S., Junier, P., Imhoff, J. F., and Witzel, K.-P.: Comparative analysis of ammonia monooxygenase ( $a m o A)$ genes in the water column and sediment-water interface of two lakes and the Baltic Sea, FEMS Microbiol. Ecol., 66, 367-378, 2008.

Kruskal, J. B.: Multidimensional scaling by optimizing goodness of fit to a non-metric hypothesis, Psychometrika, 29, 1-27, 1964a.

Kruskal, J. B.: Nonmetric multidimensional scaling - a numerical method, Psychometrika, 29, 115-129, 1964b.

Lepš, J. and Šmilauer, P.: Multivariate analysis of ecological data using CANOCO, Cambridge University Press, Cambridge, 2003.

Lam, P., Jensen, M. M., Lavik, G., McGinnis, D. F., Müller, B., Schubert, C. J., Amann, R., Thamdrup, B., and Kuypers, M. M. M.: Linking crenarchaeal and bacterial nitrification to anammox in the Black Sea, P. Natl. Acad. Sci. USA, 104, 7104-7109, 2007.
Leininger, S., Urich, T., Schloter, M., Schwark, L., Qi, J., Nicol, G. W., Prosser, J. I., Schuster, S. C., and Schleper, C.: Archaea predominate among ammonia-oxidizing prokaryotes in soils, Nature, 442, 806-809, 2006.

Lin, C. and $\mathrm{Wu}, \mathrm{X}$.: A study on characteristics of runoff amount and its important signi?cance at the Yangtze, Nature Magazine, 21, 200-205, 1999.

Lipschultz, F., Wofsy, S. C., and Fox, L. E.: Nitrogen-metabolism of the eutrophic Delaware River ecosystem, Limnol. Oceanogr., 31, 701-716, 1986.

Liu, X., Tiquia, S. M., Holguin, G., Wu, L., Nold, S. C., Devol, A. H., Luo, K., Palumbo, A. V., Tiedje, J. M., and Zhou, J.: Molecular diversity of denitrifying genes in continental margin sediments within the oxygen-deficient zone off the Pacific coast of Mexico, Appl. Environ. Microbiol., 69, 3549-3560, 2003.

Lund, M. B., Smith, J. M., and Francis, C. A.: Diversity, abundance and expression of nitrite reductase (nirK)-like genes in marine thaumarchaea, ISME J., 6, 1966-1977, 2012.

Magalhães, C., Bano, N., Wiebe, W. J., Bordalo, A. A., and Hollibaugh, J. T.: Dynamics of nitrous oxide reductase genes (nosZ) in intertidal rocky biofilms and sediments of the Douro River Estuary (Portugal), and their relation to N-biogeochemistry, Microb. Ecol., 55, 259-269, 2008.

Martens-Habbena, W., Berube, P. M., Urakawa, H., de la Torre, J. R., and Stahl, D. A.: Ammonia oxidation kinetics determine niche separation of nitrifying Archaea and Bacteria, Nature, 461, 976-979, 2009.

Merbt, S. N., Stahl, D. A., Casamayor, E. O., Martí, E., Nicol, G. W., and Prosser, J. I.: Differential photoinhibition of bacterial and archaeal ammonia oxidation, FEMS Microbiol. Lett., 327, 4146, 2012.

Mincer, T. J., Church, M. J., Taylor, L. T., Preston, C., Karl, D. M., and DeLong, E. F.: Quantitative distribution of presumptive archaeal and bacterial nitrifiers in Monterey Bay and the North Pacific Subtropical Gyre, Environ. Microbiol., 9, 1162-1175, 2007.

Moore, W. S., Sarmiento, J. L., and Key, R. M.: Tracing the Amazon component of surface Atlantic water using ${ }^{228} \mathrm{Ra}$, salinity and silica, J. Geophys. Res., 91, 2574-2580, 1986.

Mosier, A. C. and Francis, C. A.: Denitrifier abundance and activity across the San Francisco Bay estuary, Environ. Microbiol. Rep., 2, 667-676, 2010

Nogales, B., Timmis, K. N., Nedwell, D. B., and Osborn, A. M.: Detection and diversity of expressed denitrification genes in estuarine sediments after reverse transcription-PCR amplification from mRNA, Appl. Environ. Microbiol., 68, 5017-5025, 2002.

Oakley, B. B., Francis, C. A., Roberts, K. J., Fuchsman, C. A., Srinivasan, S., and Staley, J. T.: Analysis of nitrite reductase (nirK and $n i r S$ ) genes and cultivation reveal depauperate community of denitrifying bacteria in the Black Sea suboxic zone, Environ. Microbiol., 9, 118-130, 2007.

Ouverney, C. C. and Fuhrman, J. A.: Marine planktonic archaea take up amino acids, Appl. Environ. Microbiol., 66, 4829-4833, 2000.

Park, B.-J., Park, S.-J, Yoon, D.-N., Schouten, S., Damsté, J. S. S., and Rhee, S.-K.: Cultivation of autotrophic ammoniaoxidizing archaea from marine sediments in coculture with sulfur-oxidizing bacteria, Appl. Environ. Microbiol., 76, 75757587, 2010. 
Purkhold, U., Pommerening-Röser, A., Juretschko, S., Schmid, M. C., Koops, H.-P., and Wagner, M.: Phylogeny of all recognized species of ammonia oxidizers based on comparative 16S rRNA and $a m o A$ sequence analysis: Implications for molecular diversity surveys, Appl. Environ. Microbiol., 66, 5368-5382, 2000.

Renaud, M.: Hypoxia in Louisiana coastal waters during 1983: implications for fisheries, Fish. B-Noaa, 84, 19-26, 1986.

Risgaard-Petersen, N., Rysgaard, S., Nielsen, L. P., and Revsbech, N. P.: Diurnal variation of denitrification and nitrification in sediments colonized by benthic microphytes, Limnol. Oceanogr., 39, 573-579, 1994.

Ruiz-Rueda, O., Trias, R., Garcia-Gil, L. J., and Bañeras, L.: Diversity of the nitrite reductase gene nirS in the sediment of a freewater surface constructed wetland, Int. Microbiol., 10, 253-260, 2007.

Rysgaard, S., Risgaard-Petersen, N., Nielsen, L. P., and Revsbech, N. P.: Nitrification and denitrification in lake and estuarine sediments measured by the ${ }^{15} \mathrm{~N}$ dilution technique and isotope pairing, Appl. Environ. Microbiol., 59, 2093-2098, 1993.

Santoro, A. E.: Microbial nitrogen cycling at the saltwaterfreshwater interface, Hydrogeol. J., 18, 187-202, 2010.

Santoro, A. E., Boehm, A. B., and Francis, C. A.: Denitrifier community composition along a nitrate and salinity gradient in a coastal aquifer, Appl. Environ. Microbiol., 72, 2102-2109, 2006.

Santoro, A. E., Francis, C. A., de Sieyes, N. R., and Boehm, A. B.: Shifts in the relative abundance of ammonia-oxidizing bacteria and archaea across physicochemical gradients in a subterranean estuary, Environ. Microbiol., 10, 1068-1079, 2008.

Santoro, A. E., Casciotti, K. L., and Francis, C. A.: Activity, abundance and diversity of nitrifying archaea and bacteria in the central California Current, Environ. Microbiol., 12, 1989-2006, 2010.

Schloss, P. D. and Handelsman, J.: Introducing DOTUR, a computer program for defining operational taxonomic units, and estimating species richness, Appl. Environ. Microbiol., 71, 1501-1506, 2005.

Schmidt, I.: Nitric oxide: interaction with the ammonia monooxygenase and regulation of metabolic activities in ammonia oxidizers, Method. Enzymol., 7, 121-135, 2008.

Schmidt, I., Bock, E., and Jetten, M. S.: Ammonia oxidation by Nitrosomonas eutropha with $\mathrm{NO}_{2}$ as oxidant is not inhibited by acetylene, Microbiology, 147, 2247-2253, 2001.

Seitzinger, S., Harrison, J. A., Böhlke, J. K., Bouwman, A. F., Lowrance, R., Peterson, B., Tobias, C., and Van Drecht, G.: Denitrification across landscapes and waterscapes: a synthesis, Ecol. Appl., 16, 2064-2090, 2006.

Shen, J., Zhang, L., Zhu, Y., Zhang, J., and He, J.: Abundance and composition of ammonia-oxidizing bacteria and ammoniaoxidizing archaea communities of an alkaline sandy loam, Environ. Microbiol., 10, 1601-1611, 2008.

Stahl, D. A. and de la Torre, J. R.: Physiology and diversity of ammonia-oxidizing archaea, Annu. Rev. Microbiol., 66, 83-101, 2012.
Taylor, P. G. and Townsend, A. R.: Stoichiometric control of organic carbon-nitrate relationships from soils to the sea, Nature, 464, 1178-1181, 2010.

Teira, E., Van Aken, H., Veth, C., and Herndl, G. J.: Archaeal uptake of enantiomeric amino acids in the meso- and bathypelagic waters of the North Atlantic, Limnol. Oceanogr., 51, 60-69, 2006.

Ter-Braak, C. J. F.: CANOCO - an extension of DECORANA to analyze species-environment relationships, Hydrobiologia, 184, 169-170, 1989.

Tiquia, S. M., Masson, S. A., and Devol, A.: Vertical distribution of nitrite reductase genes (nirS) in continental margin sediments of the Gulf of Mexico, FEMS Microbiol. Ecol., 58, 464-475, 2006.

Wang, B.: Cultural eutrophication in the Changjiang (Yangtze River) plume: history and perspective, Estuar. Coast. Shelf S., 69, 471-477, 2006.

Wang, B.: Hydromorphological mechanisms leading to hypoxia off the Changjiang estuary, Mar. Environ. Res., 67, 53-58, 2009.

Wang, B., Wei, Q., Chen, J., and Xie, L.: Annual cycle of hypoxia off the Changjiang (Yangtze River) Estuary, Mar. Environ. Res., 77, 1-5, 2012.

Wankel, S. D., Mosier, A. C., Hansel, C. M., Paytan, A., and Francis, C. A.: Spatial variability in nitrification rates and ammoniaoxidizing microbial communities in the agriculturally impacted Elkhorn Slough estuary, California, Appl. Environ. Microbiol., 77, 269-280, 2011.

Ward, B. B.: Nitrification and denitrification: probing the nitrogen cycle in aquatic environments, Microb. Ecol., 32, 247-261, 1996.

Wei, H., He, Y., Li, Q., Liu, Z., and Wang, H.: Summer hypoxia adjacent to the Changjiang Estuary, J. Mar. Syst., 67, 292-303, 2007.

Wuchter, C., Abbas, B., Coolen, M. J. L., Herfort, L., van Bleijswijk, J., Timmers, P., Strous, M., Teira, E., Herndl, G. J., Middelburg, J. J., Schouten, S., and Damsté, J. S. S.: Archaeal nitrification in the ocean, P. Natl. Acad. Sci. USA, 103, 12317-12322, 2006.

Xia, X., Yang, Z., and Zhang, X.: Effect of suspended-sediment concentration on nitrification in river water: importance of suspended sediment-water interface, Environ. Sci. Technol., 43, 3681-3687, 2009.

Yan, J., Haaijer, S. C. M., Op den Camp, H. J. M., van Niftrik, L., Stahl, D. A., Könneke, M., Rush, D., Damsté, J. S. S., Hu, Y. Y., and Jetten, M. S. M.: Mimicking the oxygen minimum zones: stimulating interaction of aerobic archaeal and anaerobic bacterial ammonia oxidizers in a laboratory-scale model system, Environ. Microbiol., 14, 3146-3158, 2012.

Yan, W., Mayorga, E., Li, X., Seitzinger, S. P., and Bouwman, A. F.: Increasing anthropogenic nitrogen inputs and riverine DIN exports from the Changjiang River basin under changing human pressures, Global Biogeochem. Cy., 24, GB0A06, doi:10.1029/2009GB003575, 2010.

Zhu, Z., Zhang, J., Wu, Y., Zhang, Y., Lin, J., and Liu, S.: Hypoxia off the Changjiang (Yangtze River) Estuary: Oxygen depletion and organic matter decomposition, Mar. Chem., 125, 108-116, 2011.

Zumft, W. G.: Cell biology and molecular basis of denitrification, Microbiol. Mol. Biol. Rev., 61, 533-616, 1997. 